\title{
Introduction: Perspectives on Cultural Aging at a Glance
}

Demographic transformation resulting from low fertility and high life expectancy in developed and developing countries has led to an increase in the numbers of elderly people living in those countries. Moreover, low birth rates, changing family structures, and economic and political crises causing migration and flight are having a significant impact on intergenerational relationships, social welfare systems, the job market, and on what elderly people (can) expect from their retirement and environment. Due to these current demographic developments and changes, the categories age and aging are quickly gaining in societal relevance and are garnering tremendous attention in various scientific and scholarly fields. Age(ing) is not only a biological and social fact but also a cultural one.

Questions of aging and demographic change, and issues of dependency and the need for care, are central concerns in Europe and in many other countries worldwide. In societies with a growing proportion of older people, concepts relating to who the elderly are and what aging means are becoming increasingly important. Ideas about what they contribute to society and what society gives them, what is known about older people, and how aging processes are evaluated are being put to the test, and the question of how older people perceive themselves is gaining significance. In all societies, concepts of life phases have developed that are reflected in images of old age. ${ }^{1}$ Demographic shifts and changes to disease profiles and cultural dynamics (e.g., to family structures, value systems, employment, health, opportunities for political and other forms of social participation) are transforming these images of age, which in turn affect the role that people who are identified as "old” assume in a society. Reflections on old age in the arts reveal not only the concepts of age, role expectations, and stereotypical notions with which we encounter this stage of life but also how expectations of age-appropriate behavior can be subverted, changed, and expanded upon. Yet our society still pays far too little attention to the potential impact made by cultural actors on policy, social programs, and medical research. The current generation and, in particular, the next generation must be prepared for an academic and economic world that comprises diverse ages and an aging workforce, and for

1 Cf. Sechster Bericht zur Lage der älteren Generation in der Bundesrepublik Deutschland: Altersbilder in der Gesellschaft. Bericht der Sachverständigenkommission an das Bundesministerium für Familie, Senioren, Frauen und Jugend. Berlin: Drucksache 17/3815, 2010.

Ә OpenAccess. (C) 2021 Andrea von Hülsen-Esch, published by De Gruyter. (cc) BY-NC-ND This work is licensed under the Creative Commons Attribution-NonCommercial-NoDerivatives 4.0 International License. https://doi.org/10.1515/9783110683042-001 
a work environment with teams of aging employees. In addition, an aging society will necessitate changes to products and services. Many efforts are being made in medicine and science to identify both processes of aging and age-related diseases, and to develop suitable strategies for their prevention and therapy. Nevertheless, these efforts cannot prevent the fact that, in most cases, older people do not feel that they are receiving proper treatment, as behavior toward them depends on patterns that are strongly determined by factors other than biological or sociological parameters. For example, thought patterns play a significant role in this context, patterns that have emerged in the course of cultural history through social practices and that have been continuously transmitted in written texts, images, films, and plays, and in oral narratives, and discourses. Literary texts as well as films and popular text genres are the media in which narratives generate a diverse range of ideas about age. These media contain memories of hybrid cultures that are relevant to current and future age-related problems, and provide an opportunity to examine the features responsible for the elements that construct a narrative, including comparisons of different cultures.

In November 2018, thirty-three experts from Germany, Great Britain, Israel, Canada, the Netherlands, Austria, Spain, and the US gathered for three days of intensive discourse at the symposium Cultural Perspectives on Aging in Hannover-Herrenhausen, highlighting the significance of the cultural factors that constitute the framework through which cultural constructions of aging can be analyzed and understood. One of the symposium's distinctive features was its integrated concept, which connected scholarly and scientific discourses from the arts and humanities, and from social, medical, and psychological fields of study. By bringing together discourses from the medical and social sciences, and from the humanities (philosophy, art theory, literary studies and history) for the first time and by drawing attention to the importance of cultural factors in the construction of notions of aging "properly," this symposium was able to highlight some new aspects of the dynamics at play in the construction of age and to raise awareness of the consequences of continuously using persistent stereotypes.

The overall objective was to examine age as the result of knowledge and cultural practices, and to discuss strategies to productively address age(ing). However, there is still a marked desideratum with regard to interdisciplinary research - combining natural, medical, social, and cultural scientific discourses - and its public dissemination. Discussions of interdisciplinary research on age(ing) in this volume not only unify the different scientific and scholarly cultures from the fields of the natural sciences, the arts, and the humanities in a new discourse, they also analyze different cultural concepts and the effects of age and aging processes. 


\section{The art of cultural aging research}

One of the particular goals of this symposium was to bring together discourses both in the various disciplines and in different discussion circles that largely take place parallel to each other. There is a large network of researchers in the Anglo-American world who, starting with gender discourses in Anglophone literary studies and sociology, have shaped age research to date (Gullette 1997; Ekerdt 2002; Palmore et al. 2005; Katz 2010; Twigg and Martin 2015). In Europe, individual representatives of the humanities have played a part in this. ${ }^{2}$ Art studies had been largely absent from this discourse but is on the cusp of becoming an integral part of research (Brockhaus 1996; Döring 1993; von Hülsen-Esch 2009, 2013b, 2015, 2018, 2021; Kampmann 2013, 2015b, 2020; Schuster-Cordone 2009). ${ }^{3}$ Psychology and ergonomics are closely tied in age research to sociology and work psychology (Kruse 2012; Ng and Feldmann 2012; Siegrist and Dragano 2007; Börsch-Supan 2009; van Dyck and Lessenich 2009; van Dyck 2020; Amann et al. 2010; Staudinger and Häfner 2008). Medical and philosophical ethics, and ancient history have been present in a diverse range of areas; here, the University of Heidelberg has played a formative role in the development of various discourses (Ehmer and Höffe 2009; Kruse 2010; Landschaftsverband Rheinland et al. 2009; Manzeschke et al. 2013; Schäfer 2011; Ehni 2014; Thane 2005; Wagner-Hasel 2012). Although there has been a significant proliferation of theories and methods in recent decades with regard to interdisciplinary cultural gerontology, attempts to define a comprehensive methodology have failed so far. Taking into consideration the globalized world, age(ing) in German-speaking countries has become an object and paradigm of discursive negotiations between different cultures of knowledge in science and scholarship, and society. Therefore, age(ing) must be perceived as an object of knowledge and a concept (van Dyck 2016; Ehmer and Höffe 2009; Elm et al. 2009; Fangerau et al. 2009; Fering

2 The research of the 'Themenkreis Kulturwissenschaftliche Altersstudien' at the University of Vienna in 2007, the research group 'Alter(n)skulturen' at the University of Düsseldorf in 2006, and the Network Aging Research (NAR) at the University of Heidelberg in 2007 marked the beginning of research in cultural parameters of aging in German speaking countries. With the founding of ENAS (European Network in Aging Studies) in 2011, European researchers joined forces, followed in 2013 by the North American Network in Aging Studies (NANAS). In Vienna, the initiative led towards the founding of the Center for Interdisciplinary Research on Aging and Care (CIRAC) in 2020.

3 The desideratum for a cultural-scientific investigation of age(ing) can also be seen in the fact that the Kunsthistorisches Institut in Florence - Max Planck Institute joint the MaxNetAgeing researcher's network of the Max-Planck-Institutes. 
et al. 2008; von Hülsen-Esch et al. 2013a, 2015). Awareness of the societal implications of aging has risen significantly and is still gaining momentum, and, with it, calls to take a holistic view of medical, cultural, psychological and sociological aspects of aging are increasing (Bratt 2018; Derckx and Lacuelle 2020; Fangerau et al. 2009; Gullette 2002; Herwig 2014, 2015, 2016a, 2016b; Pelizäus-Hoffmeister 2014; von Hülsen-Esch et al. 2019; Staudinger and Häfner 2008; Swinnen and Stoesbury 2012; Vavra 2008). If we are to do justice to the phenomenon of "age," research on this topic will have to be carried out in a cross-disciplinary manner and using a variety of methods (Breinbauer et al. 2010; von HülsenEsch et al. 2013a). Moreover, evidence of changes in theoretical approaches toward age and aging can be found in academic discourses that have been transmitted in publications and actions and that reflect time and experience. Material traces are thus visible marks of cultural, social, and political change, but can also be read as material evidence of our own identities in flux. However, the interplay between mental attitudes, mindsets that can be put into action, unconsciously held stereotypes of age(ing), and social practices can only be revealed by analyzing cultural factors.

At an individual level, people are paying more and more attention to the issues of how to grow old and where to live in old age. Concepts of age - e.g., ideas, valuations, and "images" of age(ing) - are patterns of interpretation and elementary needs at the intersection of individual and collective life. In order to develop socially relevant concepts, we need to reflect upon different forms of knowledge about age(ing) using both traditional as well as evolving norms and codes. Moreover, we need to analyze experiences shaped by society, perceptions of age, and role expectations. Expectations about what being older means to the individual, on the one hand, result in the images and self-attributions of older people and, on the other, have economic and political consequences. The roots of concepts of aging can be found in historical and philosophical ideas, and cultural traditions; we thus need to subject them to analysis and critical appraisal in order to generate new and potentially more adequate concepts for the society of the future. Therefore, and due to the multidimensionality of the concept, a broad interdisciplinary approach uniting a diversity of disciplines - including, e.g., gerontology, history, art history, cognitive psychology, the ethics and history of medicine, literature, social and occupational medicine, organizational psychology, and philosophy - must be developed in order to produce new perspectives for an aging society.

The methodological approaches in this volume range from text analysis and image interpretation to the analysis of media, and also comprise both qualitative methods (biographical interviews, individual case studies, etc.) and quantitative methods from the empirical social sciences (medical examination, surveys, ob- 
servations, laboratory experiments, and field studies, etc.). Psychology's empirical approach makes an important contribution to the measurability of cultural factors, while media - including literary and documentary texts, images and films - not only contribute to the methodological diversity as reflections of social and cultural change but also instigate processes of consciousness and provoke behavioral changes among their readers and viewers due to the way that they address them. This potential for reflection must be utilized widely in order to find out which artistic artifacts, historical documents, and quantitative and qualitative studies convey which concepts of aging for individuals as well as for different social groups and societies. Cultural aspects of aging include the issues of which generational relationships are constructed, which ethical questions are touched upon, and which spaces of possibility are opened up for alternative ways of thinking and acting. There is still a lack of intercultural comparison that could provide the basis for fundamental reflections about how people want to age in certain phases of their lives. Based on the assumption that age and aging - for example in Israel, Japan, North America, Africa, but also within Europe - are constructed differently depending on cultural norms and cultural narratives, the cultural parameters of specific countries need to be integrated more thoroughly into research on aging. The topic of age(ing) is ideally suited to outline new concepts of inter- and transdisciplinarity, and highlights how important it is to apply the results gained from an intercultural approach in society in order to adequately meet the challenges of aging societies and societies characterized by migration.

Future research needs to bridge the gaps between the humanities, the natural and medical sciences, and the social sciences by utilizing the qualitative results of projects from the humanities (art history, philosophy, literature and film studies, history) and testing their impact on contemporary society by applying the methods of empirical research. This means that we need to find a specific scholarly value by creating fundamental links between these disciplines and reflecting upon what the "cultural age(ing)" in the title of this book represents. By reflecting upon current social practices in light of images of age(ing) that have developed through history, we would like to encourage the multifaceted transfer of scientific and scholarly insights into practice and to identify behavior that has been insufficiently questioned in both the private and institutional treatment of people in need of care.

Considering how this subject area has grown, interdisciplinary cooperation should also be directed at the concepts of "active aging" and "successful aging," which have so far been addressed in the social sciences and economics (Avramov 2003; Baltes and Baltes 1990; van Dyck et al. 2013; Götz et al. 2006; Katz 2013; Katz and Calasanti 2015; Schneider et al. 2015; Schulte et al. 2018). Given 
the serious demographic challenges facing us both now and in the future, there is an urgent need to better understand the societal and personal conditions required in order for older people to make productive contributions, not only to the economy but also in their interactions with other individuals, to communities, organizations, and society at large. At the same time, there is a need to analyze individual and societal expectations of productivity in older age, as well as the consequences of those expectations. The goal of the concept of "active aging" is to normatively and positively preserve the active and self-determined role of the elderly in society, which is accompanied by the economic objective of activating older workers and keeping them in the workforce for as long as possible (OECD 2000; United Nations Economic Commission for Europe 2016). ${ }^{4}$ Findings on persistent patterns of thought may change our entire work culture: negative stereotypes of aging and age claim that older people are less flexible and creative, that they perform worse physically and mentally, and are less able to learn. These notions very likely have a negative impact on older employees' perceptions of their own ability to work, the way they are treated by others, especially by their superiors, and their role in an organization.

In 2003, the World Health Organization expanded upon the notion of "active aging," coming up with the concept of "productive aging," which it defines more comprehensively as "the continuing participation of older people in social, economic, cultural, spiritual, and civic-political life” (World Health Organization 2003; Morrow-Howell et al. 2001). This approach could be a point of departure, taking into account new forms of participation in the job market in older age, e.g., by considering the issue of replacing salaried employment with voluntary work in older adulthood (Cole and Macdonald 2015; Schulte et al. 2018). In contrast to "successful aging," "productive aging" focusses more narrowly on mental and behavioral outcomes while referring more explicitly to societal values and norms (Schmitt 2004). ${ }^{5}$ In connection with the debate about productivity, it is also necessary to investigate life stages in which the boundaries and transitions of productivity and their historical conditions are addressed (von HülsenEsch 2018, 2021; Kampmann 2015a; Kriebernegg and Maierhofer 2013; Schäfer 2008, 2010; Sears 1986).

4 The discourse was thus oriented towards the possibilities of a lifestyle in old age on the background of an instrumentalist and economistic understanding of productivity.

5 Thus, the modern understanding of PA developed out of a broader concept of productivity, which is not only associated with the production of goods in the working world but also encompasses the participation and integration of older adults. 


\section{Cultural Perspectives on Aging: A symposium}

The symposium brought together researchers who had only been aware of each other in different groupings or who had not yet had any contact to certain research. What was special about this interdisciplinary event that took various epochs into consideration was that, during the conference, all participants became aware of the extent to which the meaning of life, bodies, and society, and the connections between them, can be consciously processed and approached for implementation in practice by analyzing and reflecting upon discourses both historical and current. Intercultural comparisons, gender-specific differences, and phenomena of productivity in old age were as much the subject of the papers as questions of longevity with regard to future generations. This clearly revealed the role played by thought patterns that have emerged in the course of cultural history in visual imprints, narratives, and social and discursive practices. Physical changes and how they are addressed - as "attacks" or transitions - were visualized directly and particularly vividly in a lecture-performance by Susanne Martin.

Different perspectives on age(ing) - understood as a cultural construction where "society" is also understood as culturally determined - have made it clear that previous approaches to this decisive phase of life have been very one-sided and that an interdisciplinary and comparative cultural collaboration that takes cultural parameters much more strongly into consideration can develop new strategies for aging societies. Therefore, alongside technical contributions, discussions focused on the political, social, and cultural conditions that shape the way we view and address old age, such as care institutions; the art education departments of museums, theaters, and opera houses; the transfer and assessment of knowledge by physicians and health professionals; improving working conditions for older people through better ergonomics; and improving the ability to work in aging societies.

The various contributions to the conference analyzed the different cultural concepts and implications of age(ing) and aging processes. In six sections, the conference took up well-known, widespread theories of aging such as cultural gerontology and ageism and examined gender and role expectations in old age not only from a cultural studies perspective but also by taking into account cultural diversity. It reflected on ethical issues and on the role played by art in those issues and shed light on the finding that the incorporation of artistic practices - creativity and proximity to art - can improve both awareness of the processes of age and aging, and quality of life for seniors and dementia patients. Participants discussed how new technologies can be made fruitful for the every- 
day lives of the elderly and how they can be used to address old age in a nondiscriminatory way, as well as analysis of the interplay between working conditions, health, and the ability of employees to work at older ages. These studies are just as relevant for transferring the findings to the worlds of work and politics as the issue of the conditions under which older people want to work beyond retirement age. This volume presents ten of the contributions from the symposium, focusing on the domains of psychology, gerontology, the history and ethics of medicine, American studies and literature, art history, and artistic interventions.

The contribution by Andreas Kruse, "Life Structure, Spirituality, and Transcendence: A Theoretical, Empirical, and Ethical Approach to Human Existence in Old Age," begins with a thematic analysis of personality in old age: what concerns or life issues influence the experiences of old people? This thematic analysis points to a variety of life issues, which - in a further step - are understood as an expression of self-design (or self-responsibility) and world design (co-, shared or joint responsibility). "Self-design" designates people's need for an independent and responsible life, including the even more extensive need to grow emotionally and mentally in old age as well as at earlier ages; moreover, the spiritual growth of many people can be seen as a further component of this growth. "World design" is the human need to do something for other people, to care for them, to transfer knowledge to and reflect upon experience with successive generations. The author argues that an important task for our society is to gain a more comprehensive understanding of age, which also means gaining a more comprehensive understanding of the person. In many cases, aging and old age are reduced to mere physical and neurocognitive processes, which neglects emotional, practical, social communicative, aesthetic, and spiritual qualities. Only when these aspects are systematically explored and addressed will the need for self-design and world design become visible in old age as well and be better addressed and realized. This article also discusses an important basis of creativity and transcendence - as a starting point for spirituality and religiosity. Creativity and transcendence are illustrated using the example of the composer Johann Sebastian Bach.

In his article "Historical Reflections on the Ethics of Aging: Examples from the Sixteenth Century," Daniel Schäfer presents us with examples of the ethical dimensions of aging in relation to an earlier century. He collects historical references to moral behavior in old age from various text sources from the late sixteenth century written by Gerolamo Cardano and Gabriele Paleotti, and compares them with the current concept of the ethics of old age. From a historical perspective, the author argues that old age is not just an anthropological constant but a cultural construct, formed by stereotypes and images both negative 
and positive, and influenced by external factors such as labor conditions, income, and medical and technical opportunities. He demonstrates that ethical issues regarding the elderly are not independent of time, that the result of ethical discourse depends on the premises of the discussants and the atmosphere of the respective discourse, and that an ethics of old age must be related to practice.

Heiner Fangerau, Nils Hansson, and Vasilija Rolfes examine ethics in relation to the increasing technization of how the elderly are treated in their article entitled "Electronic Health and Ambient Assisted Living: On the Technization of Aging and Responsibility”. The authors consider intergenerational responsibility as a key concept that must be included in ethical evaluations, against which the goals of ambient assisted living tools must be tested. Assuming that the objective of using, e.g., mobile health technologies is to enable wellbeing, safety, and autonomous living for older people while limiting the burden of care on younger people, all measures to achieve that objective, as the authors argue, must be evaluated against human rights and human dignity, and conflicting values. By discussing the idea of responsibility for the care of older people, the authors conclude that there is still a need for clear, human-bound, transparent, and interruptible decision-making hierarchies in the use of technological systems.

The first contributions, which highlight the psychological and philosophical dimensions of how we view and address old age and its implications for our actions, are followed by two investigations that focus on ageism. In her article "Not Your Grandmother's Ageism? Ageism Throughout the Life Course," Erin Lamb explores the idea of ageism using the example of young people: since Robert Butler first coined the term in 1969, ageism has been used most often to refer to prejudice against older people, and age studies has primarily focused on aging into old age. But age discrimination is not unique to later life: a recent survey of twenty-nine European countries carried out by Bratt et al. (2018) found "higher levels of perceived age discrimination among younger people than among older people" (176). Erin Lamb explores the utility of ageism as a concept applied to younger people and how juvenile ageism in particular plays out. She argues that age studies should address ageism throughout the life course, even though the ageism experienced at the two poles of the life course are not fully equivalent in structure or consequence. In her conclusion, she addresses some of the possible gains that can be made by approaching ageism as a life course concern, e.g., the opportunity to generate more intergenerational solidarity and to reflect upon all age identities more critically.

Heike Hartung's essay “Confronting Loss when 'Life Changes in the Instant': Ageism and Successful Aging in the 'Case' of Joan Didion” examines two different interacting narratives against the background of recent definitions of ageism and successful aging as social and cultural constructions, using the example of 
the American writer and journalist Joan Didion, who became a media icon in her early eighties, as a "fourth-ager." In 2015, she became the face of the Parisian luxury brand Céline and, in 2017, her nephew Griffin Dunne made her the subject of the Netflix documentary Joan Didion: The Center Will Not Hold. While Didion has thus become a media icon of successful oldest age, her cultural significance as a journalist and writer has been enhanced by the publication of her two memoirs based on her experiences of devastating loss. She examines her grief after the sudden death of her husband in The Year of Magical Thinking (2005) and explores the subjects of aging, illness, and death in Blue Nights (2011), her memoir to her only daughter Quintana, who died two years after her father. By analyzing these two literary texts, Heike Hartung shows how this writer reflects upon and counteracts aspects of American age ideology and ageism.

The next section assembles contributions that address the language- and image-based stereotypes in arts - theater, literature, and the visual and performing arts - that shape our concepts of aging. In her article "Exploring Old Age Theatrically: The Case of Three British Senior Theater Companies," Núria Casado-Gual explores the value of theater plays in age research and aging societies. Her starting point is the article “The Play's The Thing': Theatre as a Scholarly Meeting Ground in Age Studies” by Valerie Barnes Lipscomb (2012), who argues that theater studies can enrich the interdisciplinary study of aging from at least three angles: as a means of analyzing the phenomenon of ageism, especially through the study of plays and the analysis of performances; as an instrument to develop a narrative approach to aging and thus to understand old age through its diverse and subjective character; and, finally, by taking into account the "performative" aspect of age and aging, which the theater is a natural means of expressing. The author takes this triple perspective as general framework and regards it as a potential source of exchange between academics, artists, and the community to explore three British senior theater companies (Ages and Stages, Newcastle-under-Lyme; Feeling Good Theatre Company, Leeds; Elders Company, Manchester) that contribute to enriching an "age-wise" circle of conversation between the community, and artistic and academic domains. Her analysis is based on fieldwork conducted with the directors, associated artists, and actors of the three senior theater companies. The author comes to the conclusion that the three companies offer diverse models of age performativity and age ideology, where old age is presented as a dynamic category, and that the affirmative model of aging favored by these ensembles contrasts significantly with the narrative of decline predominant in the mainstream.

In her paper "A Spinster with a Twist: The Amateur Sleuth and Perspectives on Aging and Gender in the Sunday Philosophy Club Series,” Emma DomínguezRué examines the figure of the amateur spinster detective in contemporary detec- 
tive fiction. As a popular genre, detective fiction portrays cultural structures and their evolution; in recent decades it has taken up a political agenda that explores and scrutinizes the role of women and the cultural construction of women's lives. Even though contemporary female detectives have taken a decided step toward challenging stereotypes in recent decades - not only with regard to the construction of the detective character but also toward overhauling the genre itself (Klein 1995) - social constructs still offer a predominantly negative view of the aging process, particularly as it affects women. In detective fiction as in life, “the double standard of aging," as expressed by Susan Sontag (1997), combines ageism with sexism in a process of sexual disqualification that patriarchal discourse imposes upon women once they become "too old" to be sexually enticing to men. This contribution briefly outlines the evolution of amateur detectives and their interaction with aging and gender and offers a case study that explores the figure of the amateur sleuth Isabel Dalhousie, who provides a good example of the character's constant transformation by marrying a much younger man and having two children well after her period of maximum eligibility as a woman according to conventional social standards has ended. In this sense, Dalhousie embodies a different image of a detective, one that does not conform either to the genre's character conventions or to roles socially ascribed to a woman of her age. The Sunday Philosophy Club series and the character of Isabel Dalhousie unmask persistently negative cultural discourses about women and aging, and existing prejudices against middle-aged women, while revealing that, in fiction as well as fact, new choices are actually available for women out and away from those stereotypes.

In her essay “ \pm 100: Old Age and New Photography,” Hanna Baro discusses three projects by a new generation of photographers, recent graduates of a twoyear masterclass at the Ostkreuzschule für Fotografie in Berlin, who negotiate the topics of aging and old age from different perspectives. The photographs by Magdalena Stengel, Natalya Reznik, and Heidi Krautwald each deal with different aspects of aging and its implications for us as individuals and social beings. Stengel's work provides a poetic document of old age through the personal history of male and female centenarians; Reznik's two projects show two quite different aspects of female aging: a utopian process of aging, where women are still defined by their beauty, and an honest, sometimes harsh portrayal of the social, psychological, and physical effects of age; and Krautwald continues a photographic tradition of work that utilizes the periods between photographs of the same people at different stages in their life. The three artists cover a broad spectrum of ages: from extremely old age (Stengel) to middle age (Reznik) to young and middle age, as well as the period between those three life stages (Krautwald). 
The last two contributions come from the performing arts and reveal potential ways of approaching age and dementia. Theater, opera, ballet, and performance art - including members of the affected generation itself - have been increasingly engaging with the topics of "age," "aging" and dementia for about fifteen years. The contribution by the choreographer Susanne Martin documents her lecture-performances as artistic research: she has been working on the subject of age(ing) since 2003. Between 2011 and 2016, she made age(ing) the topic of her practice during her research $\mathrm{PhD}$ in dance studies. For the very specific conditions of the academic context, she developed dance lectures on age(ing), which combine performance and discussion scenes from age-critical or anocritical stage works. In her performance Dancing Age(ing): Performing Ambiguity, she explores what dance has to offer in terms of alternative ways of doing and representing age(ing). In particular, she asks how contemporary dance can address the ambiguity and multiplicity of living through time, and how it can avoid repeating stereotypical progress-peak-decline narratives. She contributes to a critical understanding of age(ing) within and beyond theater spaces by utilizing the creative and reflective tools and methods that she has developed as a dancer and performer.

Artistic Director Birgit Meyer provides an insight into the work performed by the Cologne Opera with people suffering from dementia. As part of the project Oper für Jung und Alt - Opera for Every Age, elderly people and dementia patients attend selected performances staged by the Cologne Children's Opera, which are suitable for both children and the elderly. Together, they experience the performance in close proximity to the artists, allowing the music and the dramatic art to have an immediate effect on the audience. This new approach toward dementia not only evokes positive feelings and memories in those affected but also creates the basis for intergenerational experiences that are increasingly being lost in the present-day world.

The approaches taken by the various contributions in this publication go beyond existing research projects and schools that focus on specific aspects of age(ing), and have been made possible by the generous support of the Volkswagen Foundation. I would like to express my sincere thanks to the foundation for hosting the conference at Schloss Herrenhausen, a venue that had a decisive impact on the discussion-friendly atmosphere. I would also like to warmly thank the publishing house De Gruyter for its excellent cooperation, Jon Templeman and Lydia White for their accurate copy-editing, and Ann-Kathrin Illmann for her tireless efforts carrying out the unavoidable editorial work. 


\section{Works cited}

Amann, Anton, Günther Ehgartner, and David Felder. Sozialprodukt des Alters: Über Produktionswahn, Alter und Lebensqualität. Vienna, Cologne, and Weimar: Böhlau, 2010.

Avramov, Dragana, and Miroslava Maskova. Active Ageing in Europe. Strasbourg: Council of Europe Publishing, 2003.

Baltes, Paul B., and Margret M. Baltes. "Psychological Perspectives on Successful Aging: The Model of Selective Optimization with Compensation.” Successful Aging. Eds. Paul B. Baltes and Margret M. Baltes. Cambridge: Cambridge University Press, 1990. 1-34.

Börsch-Supan, Axel, Marcel Erlinghagen, Karsten Hank, Hendrik Jürges, and Gert G. Wagner. Eds. Produktivität in alternden Gesellschaften. Stuttgart: Wissenschaftliche Verlagsgesellschaft, 2009.

Bratt, Christopher, Dominic Abrams, Hannah J. Swift, Christin-Melanie Vauclair, and Sibilia Marques. "Perceived Age Discrimination Across Age in Europe: From an Ageing Society to a Society for All Ages.” Developmental Psychology 54.1 (2018): 167-180.

Breinbauer, Ines Maria, Dieter Ferring, Miriam Haller, and Hartmut Meyer-Wolters. Eds. Transdisziplinäre Alternsstudien als disziplinäre Ko-Konstruktion. Würzburg: Königshausen \& Neumann, 2010.

Brockhaus, Christoph. Ed. Altersbildnisse in der abendländischen Skulptur (exh. cat.). Duisburg: Wilhelm Lehmbruck Museum, 1996. 42-59.

Cole, Marilyn B., and Karen Crane Macdonald. Productive Aging: An Occupational Perspective. Thorofare: SLACK, 2015.

Derckx, Peter, and Hanne Laceulle. "Humanism and Aging." The Oxford Handbook of Humanism. Ed. Anthony B. Pinn. Online: January 2020, www.oxfordhandbooks.com. DOI: 10.1093/oxfordhb/9780190921538.013.18.

Döring, Thomas. "Bilder vom alten Menschen: Anmerkungen zu Themen, Funktionen, Ästhetik." Bilder vom alten Menschen in der niederländischen und deutschen Kunst 1550-1750. Braunschweig: Herzog Anton Ulrich-Museum, 1993. 17-36.

Ehmer, Josef, and Otfried Höffe. Eds. Bilder des Alterns im Wandel: Historische, interkulturelle, theoretische und aktuelle Perspektiven. Stuttgart: Wissenschaftliche Verlagsgesellschaft, 2009.

Ekerdt, David J. Ed. Encyclopedia of Aging. New York: Macmillan Reference USA, 2002.

Ehni, Hans-Jörg. Ethik der Biogerontologie. Wiesbaden: Springer VS, 2014.

Elm von der Osten, Dorothee, Thorsten Fitzon, Sandra Linden, and Kathrin Liess. Eds. Alterstopoi: Das Wissen von den Lebensaltern in Literatur, Kunst und Theologie. Berlin: de Gruyter, 2009.

Fangerau, Heiner, Monika Gomille, Henriette Herwig, Christoph auf der Horst, Andrea von Hülsen-Esch, Johannes Siegrist, and Jörg Vögele. Eds. Alterskulturen und Potentiale des Alter(n)s. Berlin: Akademie-Verlag, 2009.

Ferring, Dieter, Miriam Haller, Hartmut Meyer-Wolters, and Tom Michels. Eds. Soziokulturelle Konstruktion des Alters: Transdisziplinäre Perspektiven. Würzburg: Königshausen \& Neumann, 2008.

Götz, Rudolf, Isabel Naylon, and Ehrenfried Natter. "Productive Ageing in Europa: Recherchestudie zu Good Practice in ausgewählten Mitgliedstaaten der EU.” AMS report 54 (2006). 
Gullette, Margaret Morganroth. Declining to Decline: Cultural Combat and the Politics of the Midlife. Charlottesville: University of VA P, 1997.

Gullette, Margaret Morganroth. "Age Studies as Cultural Studies." Handbook of the Humanities and Aging. Eds. Thomas R. Cole, Robert Kastenbaum, and Ruth E. Ray. New York: Springer, 2000. 214-234.

Herwig, Henriette. Ed. Merkwürdige Alte: Zu einer literarischen und bildlichen Kultur des Alter(n)s. Bielefeld: transcript, 2014.

Herwig, Henriette. "Literarische Alterskonstruktionen als Medien der Erinnerung und der Reflexion epochalen Wandels: Theodor Fontanes Der Stechlin, Wilhelm Raabes Altershausen und Christa Wolfs Leibhaftig." Alter(n) neu denken: Konzepte für eine neue Alter(n)skultur. Ed. Andrea von Hülsen-Esch. Bielefeld: transcript, 2015. 41-70.

Herwig, Henriette. "Literarische Demenznarrative und ihr Wert für die Medical Humanities.” Literatur und Medizin: Interdisziplinäre Beiträge zu den Medical Humanities. Eds. Pascal Fischer and Mariacarla Gadebusch Bondio. Heidelberg: Winter, 2016a. 177-192.

Herwig, Henriette. "Demenz im Spielfilm: Andreas Kleinerts Mein Vater, Richard Glatzers Still Alice, Til Schweigers Honig im Kopf und Nikolaus Leytners Die Auslöschung." Alte im Film und auf der Bühne. Eds. Henriette Herwig and Andrea von Hülsen-Esch. Bielefeld: transcript, 2016b. 139-176.

Kampmann, Sabine. “Fotografische Bildwelten des Alter(n)s.” Methoden der Alter(n) sforschung: Disziplinäre und transdisziplinäre Perspektiven. Eds. Andrea von Hülsen-Esch, Miriam Seidler, and Christian Tagsold. Bielefeld: transcript, 2013. $255-266$.

Kampmann, Sabine. " 1 bis $\infty$ : Zur Visualisierung von Lebenszeit in der Kunst am Beispiel Roman Opalkas." Prozesse des Alterns: Konzepte - Narrative - Praktiken. Eds. Max Bolze, Cordula Endter, Marie Gunreben, Sven Schwabe, and Eva Styn. Bielefeld: transcript, 2015a. 89-108.

Kampmann, Sabine. "Visual Aging Studies: Exploring Images of Aging in Art History and Other Disciplines.” Age, Culture, Humanities 2 (2015b): 279-291.

Kampmann, Sabine. Bilder des Alterns: Greise Körper in Kunst und visueller Kultur. Berlin: Reimer, 2020.

Katz, Stephen, and Toni Calasanti. "Critical Perspectives on Successful Aging: Does It “Appeal More Than It Illuminates"?" The Gerontologist 55.1 (2015): 26-33. Doi.10.1093/geront/gnu027.

Katz, Stephen. “Active and Successful Aging: Lifestyle as a Gerontological Idea.” Recherches sociologiques et anthropologiques 44 (2013): 33-49.

Katz, Stephen. "Sociocultural Perspectives on Ageing Bodies." Sage Handbook of Social Gerontology. Eds. Dale Dannefer and Chris Philippson. London: Sage Publications, 2010. $357-367$.

Klein, Kathleen Gregory. Ed. Women Times Three: Writers, Detectives, Readers. Bowling Green, OH: Bowling Green University Popular Press, 1995.

Kriebernegg, Ulla, and Roberta Maierhofer. Eds. The Ages of Life: Living and Aging in Conflict? Bielefeld: transcript, 2013.

Kruse, Andreas. “ Menschenbilder und Altersbilder: Differenzierte Repräsentationen des Alters in ihrer Bedeutung für personale Entwicklungsprozesse." Menschen-Bilder: Darstellungen des Humanen in der Wissenschaft. Eds. Markus Hilgert and Michael Wink. Berlin and Heidelberg: Springer Verlag, 2012. 215-227. 
Kruse, Andreas. Ed. Potenziale im Altern. Chancen und Aufgaben für Individuum und Gesellschaft. Heidelberg: Akademische Verlagsgesellschaft AKA, 2010.

Landschaftsverband Rheinland, and LVR-LandesMuseum Bonn. Eds. Alter in der Antike: Die Blüte des Alters aber ist die Weisheit (exh. cat.). Mainz: Philipp von Zabern, 2009.

Lipscomb, Valerie Barnes. “'The Play's The Thing': Theatre as a Scholarly Meeting Ground in Age Studies." International Journal of Ageing and Later Life 7.2 (2012): 117-141.

Manzeschke, Arne, Karsten Weber, Elisabeth Rother, and Heiner Fangerau. Ergebnisse einer Studie: Ethische Fragen im Bereich Altersgerechter Assistenzsysteme. Ludwigsfelde: VDI/VDE Innovation + Technik, 2013.

Morrow-Howell, Nancy, James Hinterlong, and Michael Sherraden. Eds. Productive Ageing: Concepts and Challenges. Baltimore, MD: John Hopkins University Press, 2001.

Ng, Thomas W. H., and Daniel C. Feldman. "Evaluating Six Common Stereotypes about Older Workers with Meta-Analytical Data.” Personnel Psychology 65.4 (2012): 821-858.

OECD. Reforms for an Ageing Society: A Progress Report to G8 Employment Ministers. Paris, 2000.

Palmore, Erdman, Laurence Branch, and Diana Harris. Eds. Encyclopedia of Ageism. New York: Haworth Press, 2005.

Pelizäus-Hoffmeister, Helga. Ed. Der ungewisse Lebensabend? Alter(n) und Altersbilder aus der Perspektive von (Un-)Sicherheit im historischen und kulturellen Vergleich. Wiesbaden: Springer VS, 2014.

Schäfer, Daniel. "Gullivers Greise und Medeas Mixturen: Frühneuzeitliche Beispiele für Langlebigkeit im medizinischen und nichtmedizinischen Kontext." Exempla medicorum: Die Ärzte und ihre Beispiele (14.-18. Jahrhundert). Eds. Mariacarla Gadebusch Bondio and Thomas Ricklin. Florence: Sismel Edizioni del Galluzzo, 2008. 219-228.

Schäfer, Daniel. Old Age and Disease in the Early Modern Medicine. London: Pickering \& Chatto, 2011.

Schmitt, Eric. "Aktives Altern, Leistungseinbußen, soziale Ungleichheit und Altersbilder." Zeitschrift für Gerontologie und Geriatrie 37.4 (2004): 280-292.

Schneider, Norbert F., Andreas Mergenthaler, Ursula M. Staudinger, and Indes Sackreuther. Eds. Mittendrin? Lebenspläne und Potenziale älterer Menschen beim Übergang in den Ruhestand. Opladen, Berlin, and Toronto: Barbara Budrich, 2015.

Schroeter, Klaus R. "Zur Doxa des sozialgerontologischen Feldes: Erfolgreiches und produktives Altern - Orthodoxie, Heterodoxie oder Allodoxie?." Zeitschrift für Gerontologie und Geriatrie 37 (2004): 51-55.

Schulte, Paul A., James Grosch, Juliann C. Scholl, and Sara L. Tamers. "Framework for Considering Productive Aging and Work." Journal of Occupational and Environmental Medicine 5.60 (2018): 440-448.

Schuster-Cordone, Caroline. Le crépuscule du corps: Images de la vieillesse feminine. Gollion: Infolio éditions, 2009.

Sears, Elizabeth. The Ages of Man: Medieval Interpretations of the Life Cycle. Princeton: Princeton University Press, 1986.

Sechster Bericht zur Lage der älteren Generation in der Bundesrepublik Deutschland: Altersbilder in der Gesellschaft. Bericht der Sachverständigenkommission an das Bundesministerium für Familie, Senioren, Frauen und Jugend. Berlin: Drucksache 17/3815, 2010. 
Siegrist, Johannes, and Nico Dragano. Rente mit 67: Probleme und Herausforderungen aus gesundheitswissenschaftlicher Sicht. Düsseldorf: Hans-Böckler-Stiftung, 2007.

Sontag, Susan. "The Double Standard of Aging." The Other Within Us: Feminist Explorations of Women and Aging. Ed. Marilyn Pearsall. Boulder, CO: Westview, 1997. 19-24.

Staudinger, Ursula, and Heinz Häfner. Eds. Was ist Alter(n)? Neue Antworten auf eine scheinbar einfache Frage. Berlin and Heidelberg: Springer, 2008.

Swinnen, Aagje, and John A. Stoesbury. Eds. Aging, Performance and Stardom: Doing Age on the Stage of Consumerist Culture. Berlin: LIT Verlag, 2012.

Twigg, Julia, and Wendy Martin. Eds. Routledge Handbook of Cultural Gerontology. New York: Routledge, 2015.

Thane, Pat. Ed. The Long History of Old Age. London: Thames and Hudson, 2005.

United Nations Economic Commission for Europe. Active Aging Index. https://statswiki.unece. org/display/AAl/Active+Ageing+Index+Home. 18 November 2016 (2 May 2021).

van Dyck, Silke. Soziologie des Alters. Bielefeld: UTB transcript, 2020.

van Dyck, Silke. "The Othering of Old Age. Insights from Postcolonial Studies." Journal of Aging Studies 39 (2016): 109-120.

van Dyck, Silke, Thomas Lessenich, Tina Denninger, and Anna Richter. "The Many Meanings of Active Ageing: Confronting Public Discourse with Older People's Stories.” Recherches sociologiques et anthropologiques. Thematic issue: The production of ageing and its relations to contemporary norms 44.1 (2013): 97-115.

van Dyck, Silke, and Thomas Lessenich. Die jungen Alten: Analysen zu einer neuen Sozialfigur. Frankfurt am Main and New York: Campus, 2009.

Vavra, Elisabeth. Ed. Alterskulturen des Mittelalters und der Frühen Neuzeit. Vienna: VÖAW 2008.

von Hülsen-Esch, Andrea. "Zeitlichkeit und die Verkörperung von Zeit: Zur kulturellen Konstruktion von Lebensalterstufen im Stundenbuch des Francesco da Barberino.” Kulturgerontologie. Eds. Franz Kolland, Vera Gallistl, and Viktoria Parisot. Vienna: Springer, 2021 (in press).

von Hülsen-Esch, Andrea, Heiner Fangerau, and Daniel Schäfer. "Kulturelle Aspekte des Alter(n)s: Die Wirkung von Altersstereotypien auf die Alltagspraxis." Zeitschrift für Gerontologie und Geriatrie 52 (Supplement 3) (2019): 165-179

von Hülsen-Esch, Andrea. "The Three Ages of Man and the Materialization of an Allegory: Inquiries on an Object at the Threshold of Modernity." Images, Improvisations, Sound and Silence from 1000 to 1800: Degree Zero. Eds. Babette Hellemans and Alissa Jones Nelson. Amsterdam: Amsterdam University Press, 2018. 55-72.

von Hülsen-Esch, Andrea. Ed. Alter(n) neu denken. Bielefeld: transcript, 2015.

von Hülsen-Esch, Andrea, Miriam Seidler, and Christian Tagsold. Eds. Methoden der Alter(n) sforschung: Disziplinäre Positionen und transdisziplinäre Perspektiven. Bielefeld: transcript, 2013a.

von Hülsen-Esch, Andrea. "Armut und Alter in der Renaissance." Armut in der Renaissance. Eds. Klaus Bergdolt, Lothar Schmitt, and Andreas Tönnesmann. Wiesbaden: Harrassowitz Verlag, 2013b. 15-50.

von Hülsen-Esch, Andrea. "Falten, Sehnen, Knochen: Zur Materialisierung des Alters in der Kunst um 1500." Alterskonzepte in Literatur, bildender Kunst, Film und Medizin. Ed. Henriette Herwig. Freiburg im Breisgau: Rombach, 2009. 13-44.

Wagner-Hasel, Beate. Alter in der Antike: Eine Kulturgeschichte. Vienna: Böhlau, 2012. 
World Health Organization. Department of Gender, Women and Health. Gender, Health and Ageing: Gender and Health Information Sheet. http://www.who.int/gender-equity-rights/ knowledge/a85586/en/. 2003 (2 May 2021). 
